\title{
$\beta$-Globin dominant control region interacts differently with distal and proximal promoter elements
}

\author{
Michael Antoniou and Frank Grosveld \\ Laboratory of Gene Structure and Expression, National Institute for Medical Research, The Ridgeway, Mill Hill, London NW7 \\ IAA UK
}

\begin{abstract}
We have studied the interaction between the dominant control region (DCR) and the promoter of the human $\beta$-globin gene. Expression analysis in MEL cells has revealed that the DCR contains a number of elements capable of replacing the upstream $(-250$ to -100$)$ erythroid-specific region of the promoter. The DCR strongly stimulates expression from a promoter possessing only a TATA box. However, this basic level of transcription is not induced upon erythroid differentiation of the cells. Mutational analysis of the minimal (-100, noninducible) promoter shows that only the combination of the DCR and the CAC/CCAAT elements provides erythroid-specific transcription. These regions act synergistically to produce full regulated expression during erythroid differentiation.
\end{abstract}

[Key Words: $\beta$-Globin; dominant control region; transcription]

Received January 29, 1990; revised version accepted March 19, 1990.

A number of erythroid and developmental specific regulatory elements have been identified within the promoter and the two downstream enhancers of the human $\beta$-globin gene. These elements confer regulated expression on the human $\beta$-globin gene when introduced in transgenic mice or erythroid cell lines (Behringer et al. 1987; Kollias et al. 1987; Trudel et al. 1987; Antoniou et al. 1988), albeit at a level considerably below that of the endogenous globin genes. A number of ubiquitous and erythroid-specific protein-binding sites within these regulatory regions have been identified (Fig. 1; deBoer et al. 1988; Wall et al. 1988), most notably for the erythroidspecific factor NF-E1. The NF-El gene has recently been cloned from mouse (Tsai et al. 1989), chicken (Evans and Felsenfeld 1989), and human (Trainor et al. 1990). In addition, it has been shown that the murine NF-El alone is incapable of inducing regulated expression on the minimal $\beta$-globin promoter (see Fig. 1) but needs to interact with at least one ubiquitous DNA-binding protein at a neighboring site (Fig. 1, CP-1 at -160 ; deBoer et al. 1988).

To achieve high levels of regulated expression, an additional regulatory region located $50-60 \mathrm{~kb}$ upstream from the $\beta$-globin gene and, hence, distal to the entire multigene cluster, is required. When this dominant control region (DCR) is linked directly to a $\beta$-globin gene, it confers high-level, gene-copy-number-dependent expression of the gene in transgenic mice and murine erythroleukemia (MEL) cells, independent of the site of integration in the host genome (Grosveld et al. 1987; Blom van Addendelft et al. 1989). The DCR confers the same char- acteristics to the other genes in the cluster $\mid \epsilon$ and $\gamma$ globin; Catala et al. 1989; Enver et al. 1989; Lindenbaum, unpubl.) and also the $\alpha$-globin gene (Behringer et al. 1989; Hanscombe et al. 1989; Ryan et al. 1989/ but does not appear to have any developmental specificity. The DCR contains four tissue-specific DNase I hypersensitive (DHS) sites over a region of $20 \mathrm{~kb}$ (Tuan et al. 1985; Forrester et al. 1987; Grosveld et al. 1987), which can be reduced to a small region containing only these DHS sites (Talbot et al. 1989). Further functional mapping of the DCR in MEL cells has shown that the region contains a considerable amount of redundancy /Collis et al. 1990); that is, DHS sites 2 and 3 provide $\sim 50 \%$ of the activity but do not act synergistically, whereas sites 1 and 4 provide, at most, $10 \%$ of the activity. However, DHS sites 1 and/or 4 can act in conjunction with sites 2 and/or 3 to boost expression levels to $>80 \%$ of the full DCR. Further work in transgenic mice has demonstrated that DHS site 1,2 , or 3 can promote gene-copy-numberdependent expression independently, although at levels of $30-70 \%$ of the full DCR (Fraser et al. 1990). Both DHS sites 2 and 3 have been reduced to a minimal fragment of $\sim 300 \mathrm{bp}$, each of which contains three binding sites for NF-E1 in addition to a number of other erythroid-specific and ubiquitous proteins (Philipsen et al. 1990; Talbot et al. 1990).

It is also important to note that the DCR possesses several properties that are not common to previously characterized cellular and viral enhancers. First, the transcriptional stimulatory function of at least three of the DHS sites (numbers 1, 2, and 4) is undetectable in 


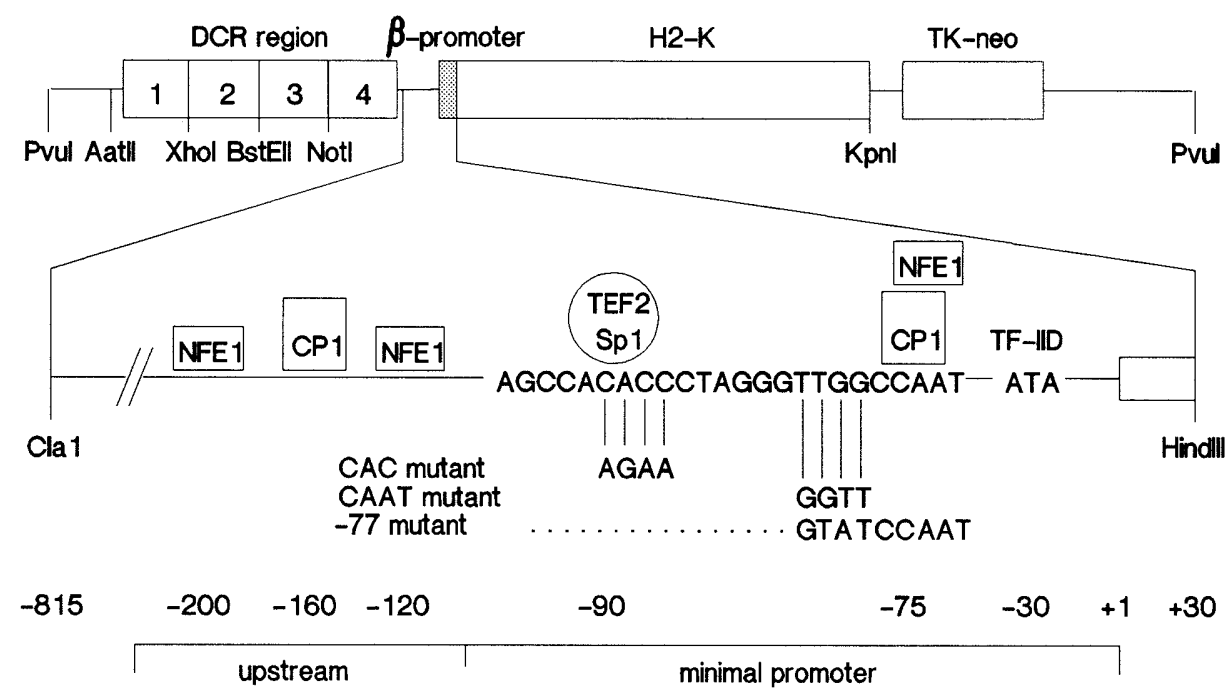

Figure 1. Structure of the $\beta \mathrm{H}-2 \mathrm{~K}-\mathrm{DCR}$ microlocus cassette and the $\beta$-globin promoter. The $\beta \mathrm{H} 2 \mathrm{~K}$ hybrid gene, consisting of the human $\beta$-globin promoter to -815 and murine $\mathrm{H}-2 \mathrm{~K}^{\mathrm{k}}$-coding sequences (see Materials and methods), was inserted between the ClaI and KpnI sites of the DCR microlocus cassette, which contains the four regions $(1-4)$ of DNase I hypersensitivity found upstream of the $\beta$-globin locus (top line; see Collis et al. 1990). The vector also possesses the TK-neo gene, which confers resistance of transfected cells to G418. The middle line illustrates the protein factor-binding sites to the part of the promoter assessed to be important for expression during erythroid differentiation (Antoniou et al. 1988; deBoer et al. 1988). The point mutants within the minimal part of the promoter that were made to selectively destroy binding of SpI and TEF-2 to the CAC region (Xiao et al. 1987) and CP-1 to the CCAAT box (Chodosh et al. 1988) are also shown. The bottom line marks positions relative to the cap site. All constructs were linearized at the PVuI site within the vector prior to transfection into MEL cells.

classical enhancer-trap experiments employing transient expression assays in cultured cells (Tuan et al. 1989|. Thus, the DCR can only be analyzed by stable transfection into erythroid cells or in transgenic mice. Of greater significance is the ability of the DCR to confer gene-copy-number-dependent expression. To date, only the T-cell-specific "enhancer" for the CD2 gene has been shown to possess similar properties (Greaves et al. 1989). On the basis of the available information, it is not clear, however, by which mechanism the DCR is able to confer high levels of regulated expression and through which parts of the $\beta$-globin promoter it is able to exert its effect. Here, we describe expression studies in MEL cells that provide a functional analysis of the interaction between the DCR and the $\beta$ globin promoter. This constitutes the first quantitative analysis of cooperative interactions between the promoter regions and erythroid-specific regulatory elements of the human $\beta$-globin gene. Our results show that the erythroid-specific upstream part of the $\beta$-globin promoter can be replaced by a complete or partial DCR and that the DCR can interact directly with a promoter that contains a only TATA box. However, all tissue-specific stimulation of transcription is mediated through the CCAAT and the CAC box regions in the minimal, downstream promoter.

\section{Results}

\section{Human $\beta$-globin promoter constructs}

The original 40-kb human $\beta$-globin minilocus (Grosveld et al. 1987) was reduced to a $6.5-\mathrm{kb}$ DCR microlocus (Talbot et al. 1989) without loss of activity. It was subse- quently shown that the two downstream enhancers of the $\beta$-globin gene could also be deleted without loss of activity (Collis et al. 1990). This allowed us to study the full activity of the DCR on just the human $\beta$-globin promoter, which itself can be regulated (Antoniou et al. 1988; deBoer et al. 1988). The promoter was linked to a murine $\mathrm{H}-2 \mathrm{~K}^{\mathrm{b}}$ reporter gene (Materials and methods; Fig. 1; Antoniou et al. 1988) and inserted into the microlocus cassette (Fig. 1; Collis et al. 1990). Deletion variants and point mutations were constructed in different combinations by use of existing (Antoniou et al. 1988; deBoer et al. 1988; Collis et al. 1990) and newly derived mutations in the promoter and DCR region of the $\beta$-globin gene.

Only the minimal promoter is essential in the presence of the DCR

The upstream part of the $\beta$-globin promoter confers inducible expression on the gene, mediated by the presence of at least one of the two NF-E1 and the $(-150)$ CP-1-binding sites (Fig. 1; deBoer et al. 1988), although it was impossible to quantitate the contribution of each of the NF-E1 sites (deBoer et al. 1988). To overcome this limitation, the original $\beta$-globin promoter mutants that delete one or more of these upstream factor-binding sites (Fig. 2; Antoniou et al. 1988) were linked to the DCR, which confers gene-copy-number-dependent expression. Each construct was introduced into MEL cells, and three stably transformed populations were isolated for each construct. RNA was isolated before and after erythroid induction of the cell population. S1 nuclease protection analysis of the $5^{\prime}$ end of the hybrid $\beta$-globin $\mathrm{H}-2 \mathrm{~K}^{\mathrm{k}}$ RNA 

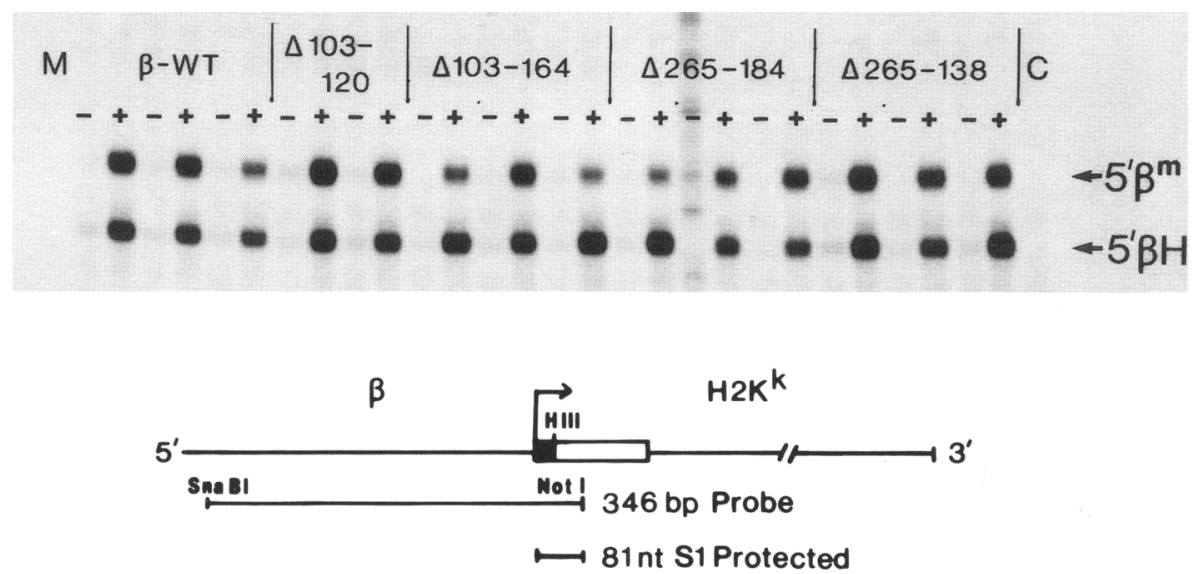

Figure 2. Analysis of upstream promoter mutants of the $\beta$-globin gene within the microlocus DCR. The wild-type ( $\beta$-WT) $\beta$-globin promoter (to -815 ) and internal deletion mutants $(\Delta)$ were linked to a murine $\mathrm{H}-2 \mathrm{~K}^{\mathrm{k}}$ reporter gene and placed within the DCR microlocus cassette (see Fig. 1). These constructs were then introduced into MEL cells, as described in Materials and methods. The S1 nuclease protection analysis of RNA $(2 \mu \mathrm{g})$ is shown from the resulting transfected populations of cells before $(-)$ and after $(+\mid 4$ days of induced erythroid differentiation. The probe used to detect the $\beta \mathrm{H}-2 \mathrm{~K}$ hybrid mRNA $\left(5^{\prime} \beta \mathrm{H}\right)$ is illustrated. The probe used to measure $\beta^{\text {mai }}$ globin mRNA levels $\left(5^{\prime} \beta^{\mathrm{m}}\right)$ is a $700-\mathrm{bp}$ HindIII-Ncol fragment that protects 96 nucleotides from the $5^{\prime}$ half of the second exon of the $\beta^{\text {mai }}$ gene (see Kollias et al. 1987). The negative control $|C|$ is RNA from uninduced, untransfected cells. The various internal deletions tested remove one or more of the factor-binding sites within the upstream promoter (see Fig. 1); $\Delta 103-120$, NF-E1; $\Delta 103-164$, NF-E1 plus CP-1; $\Delta 265-184$, upstream NF-E1; $\Delta 265-138$, upstream NF-El plus CP-1.

showed that all of the upstream deletion mutants had the same inducibility and overall levels of expression per gene when compared to the complete promoter $(\beta-\mathrm{WT})$ and the endogenous mouse $\beta^{\text {mai }}$-globin RNA (Fig. 2). This is in marked contrast to the results obtained with these deletion mutants in the absence of the DCR (Antoniou et al. 1988), when only the $\Delta 103-120$ and $\Delta 184-265$ constructs retained inducibility. We therefore conclude that the presence of the DCR completely abolishes the requirement for the erythroid-specific, upstream part of the promoter. This was confirmed when all of the upstream promoter was removed in a construct deleted to position - 103 (Fig. 3; Table 1). To determine what parts, if any, of the minimal promoter were essential to provide full expression, we linked a further set of mutants to the DCR: the -103 mutant, which contains all the non-tissue-specific elements for expression in nonerythroid cells (Grosveld et al. 1982; Dierks et al. 1983; Myers et al. 1986); a CAC box mutant and a CCAAT box mutant, both of which were constructed by in vitro oligonucleotide-directed mutagenesis to replace 4 nucleotides essential for the binding of SP1 and TEF-2 (Xiao et al. 1987; E. Spanopoulou, unpubl.); and CP-I (Chodosh et al. 1988), respectively (Fig. 1). In addition, we used the -77 mutant, which lacks both a functional CAC and CCAAT box. S1 nuclease protection analysis (Fig. 3; Table 1) of three independent stably transformed populations shows that the minimal promoter has the same levels as the complete $(-815)$ promoter. Mutagenesis of the CAC or CCAAT box produces identical results; that is, the pre- and postinduction levels of transcription have decreased $\sim 5$ to 7 -fold, but the inducibility has remained the same ( $\sim 10$-fold; Fig. 3 and inset). When both the CAC and CCAAT box are removed $(-77)$, the preinduction level of transcription remains the same as in the single CAC or CCAAT box mutants, but inducibility is lost (Fig. 3 inset). When the DCR is removed from this construct $(-77 \triangle D C R$, Fig. 3 inset), both pre- and postinduction levels of RNA drop to nondetectable levels. These results suggest that the DCR has a strong effect on the TATA box and initiation complex formation (>100-fold) to provide a low level of basic transcription before induction. This preinduction level is increased five- to sevenfold by the CAC and CCAAT box but only when both are present. Inducibility is mediated entirely through the CAC and CCAAT box, and the presence of only one of these is sufficient for full induction, albeit at lower total RNA levels. These data are in complete agreement with the $\beta$-globin levels observed in naturally occurring CAC box mutations (Orkin et al. 1982, 1984; Triesman et al. 1983).

The region of DHS sites 2 and 3 is essential for high levels of induction

To determine which of the DHS regions of the DCR could replace the upstream part of the $\beta$-globin promoter, we measured the activity of the DCR lacking DHS site 2 or site 3 , or both sites 2 and 3 on a full $(-815)$ promoter (Fig. 4, top) or a minimal (-103) promoter (Fig. 4 , bottom). The loss of both sites 2 and 3 , but not of sites 2 or 3 alone, results in a substantial decrease in the level of transcription (down to $7 \%$ ) from the full promoter. When the minimal promoter is used, the loss of sites 2 and 3 , or site 3 alone, results in a decrease to $<2 \%$ and $40 \%$, respectively. The loss of site 2 alone does not result in a significant decrease $(90 \%$ of full DCR). It therefore appears that site 3 contains sequences that can substitute for the upstream promoter elements. The low levels of expression in the absence of sites 2 and 3 pre- 


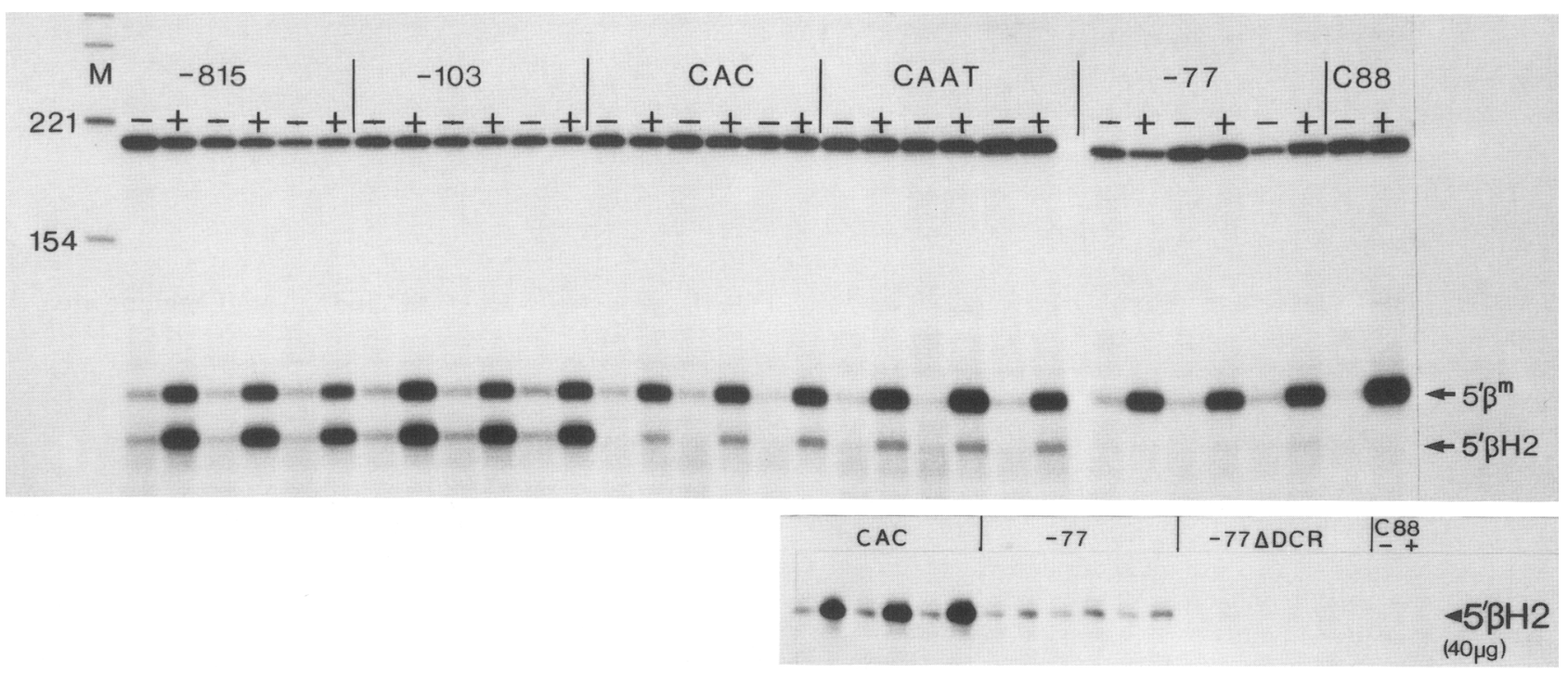

Figure 3. The DCR produces full expression from the minimal $\beta$-globin promoter. The $\beta$-globin minimal promoter $(-103)$ and variants, consisting of point mutants within the CAC and CCAAT regions, and a -77 construct, which deletes both CAC and CCAAT elements, were linked to the H-2K reporter gene in conjunction with the DCR microlocus (see Figs. 1 and 2). These constructs were then introduced into MEL cells to assess their capacity for erythroid-specific expression /see Materials and methods; Fig. 2). S1 nuclease protection analysis of RNA $(2 \mu \mathrm{g})$ is shown from preinduced $|-|$ and 4 -day-induced $|+|$ MEL cell populations transfected with the minimal promoter mutants and compared to the level of expression obtained with the full $(-815)$ promoter construct (see Fig. 2). (Inset) Analysis with $40 \mu \mathrm{g}$ of RNA from the cells carrying the CAC and -77 DCR constructs compared to a $-77 \beta \mathrm{H}-2 \mathrm{~K}$ hybrid gene in the absence of the DCR $(-77 \Delta \mathrm{DCR})$. The probes for the $\beta \mathrm{H}-2 \mathrm{~K}$ hybrid mRNA $\left(5^{\prime} \beta \mathrm{H} 2\right)$ and $\beta^{\mathrm{maj}}$-globin mRNA $\left(5^{\prime} \beta^{\mathrm{m}}\right)$ were as described in Fig. 2. RNA from untransfected cells $(\mathrm{C} 88)$ acted as a negative control. The size markers $(\mathrm{M})$ are a HinfI digest of pBR322.

clude any accurate quantitation of the effect of sites 1 and 4. We therefore carried out a more sensitive analysis of the double mutants that still have sites 1 and 4 present (HSS-1/4, Fig. 5). This shows that these sites can still provide inducibility at approximately the same level as the upstream promoter element itself /cf. -103 HSS-1/4 to $-815 \Delta D C R$ ). When both sites 1 and 4 and the distal promoter are present, they act synergistically to increase expression sevenfold $(-815$ HSS-1/4) when compared to the distal promoter or the $1 / 4$ elements (-815 $\Delta$ DCR or -103 HSS-1/4) only.

Table 1. Quantitation of relative transcription levels from the minimal $\beta$-globin promoter mutants in the presence of the DCR

\begin{tabular}{lcc}
\hline Promoter mutant & Preinduced & Postinduced \\
\hline TATA & $>0.01$ & $>0.01$ \\
DCR + TATA & 1 & 1 \\
DCR + CAC & 1 & 10 \\
DCR + CCAAT & 1 & 10 \\
DCR + CAC/CCAAT & 7 & 70 \\
\hline
\end{tabular}

Autoradiographs of the $\mathrm{S} 1$ nuclease protection analysis shown in Fig. 3 were scanned with a Joyce Loebl Chromoscan 3 densitometer. The levels of $\beta \mathrm{H}-2 \mathrm{~K}$ mRNA in pre- and postinduced MEL cells are expressed relative to the amount obtained in the DCR + TATA box combination (arbitrarily set at 1). Expression from a TATA box promoter in the absence of the DCR / top line) was below the level of sensitivity of the assay and, hence, at least 100 -fold lower than that seen in the presence of the DCR (second line). Average transfected gene copy number was the same in each population.

\section{Discussion}

Earlier work in this laboratory had indicated that the local enhancers of the human $\beta$-globin gene become redundant within the context of the microlocus DCR when expression is analyzed during erythroid differentiation of MEL cells (Collis et al. 1990). This suggested, but did not prove, that the DCR was functioning purely through the $\beta$-globin promoter. The results presented in this report confirm those initial observations. When the promoter of the human $\beta$-globin gene is linked to a murine major histocompatibility complex $\left(\mathrm{H}-2 \mathrm{~K}^{\mathrm{k}}\right)$ reporter gene within the microlocus cassette (see Fig. 1) and introduced into MEL cells, equal amounts of $\beta \mathrm{H}-2 \mathrm{~K}^{\mathrm{k}}$ and $\beta^{\text {mai }}$-globin mRNA are produced on a gene copy number basis upon induced erythroid differentiation of the transfected cells (Fig. 2). Furthermore, addition of either the gene's internal or $3^{\prime}$ enhancers (see Collis et al. 1990) upstream of the $\beta \mathrm{H}-2 \mathrm{~K}^{\mathrm{k}}$ hybrid gene did not produce any further stimulation of transcription (data not shown). Deletion analysis revealed that only the minimal part of the promoter is, in fact, sufficient for full regulated expression (Fig. 3, - 103). Thus, the upstream region of the promoter that contains the binding sites for the erythroid-specific transcription factor NF-E1 (see Fig. 1), like the enhancers, is also made completely redundant by the DCR.

Further mutational analysis indicates that at least three types of interaction are taking place between the DCR and the minimal promoter elements /quantitated in Table 1). First, the DCR increases transcription from a purely TATA box promoter by $>100$-fold to produce a 


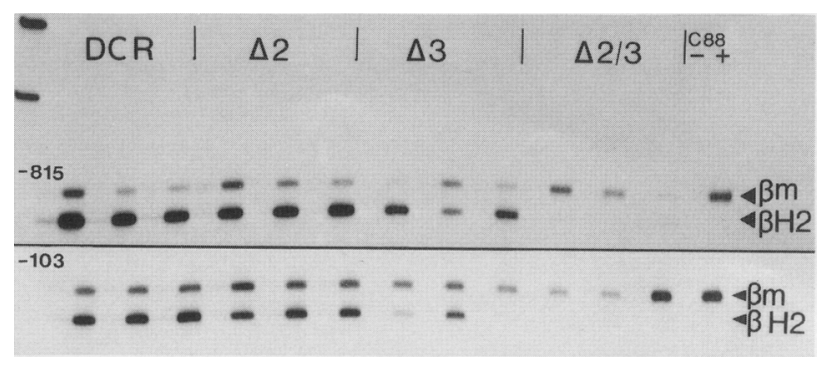

Figure 4. Effect of deleting DHS sites 2 and 3 from the DCR. The full $(-815$, top $)$ and minimal $(-103$, bottom $)$ promoter $\beta \mathrm{H}-2 \mathrm{~K}$ hybrid genes were linked to either the complete microlocus DCR, as described previously (see Figs. 1, 2, and 3 ), or to DCR deletion mutants lacking site $2(\Delta 2)$, site $3(\Delta 3)$, or both sites 2 and $3(\Delta 2 / 3)$. Analysis of RNA from MEL cell populations transfected with these constructs was exactly as described in Fig. 2. RNA from untransfected cells $(\mathrm{C} 88)$ acted as a negative control.

basic (but noninducible) steady-state level of mRNA (Fig. 3 inset; cf. -77 and $-77 \Delta \mathrm{DCR}$ ). This indicates that the DCR stimulates the formation of the transcription initiation complex. The addition of either a functional CCAAT or CAC region to the basic TATA box promoter does not alter the preinduced level of transcription but restores full induced expression upon differentiation of the MEL cells, albeit at a reduced absolute rate (Fig. 3). Finally, with the complete minimal promoter, both preand postinduced rates of transcription are increased to produce full steady-state levels of mRNA. Thus, the $\mathrm{CAC}$ and CCAAT regions can only cooperate with each other and the DCR in preinduced MEL cells when they are both present, whereas either one can promote full induction of transcription upon erythroid differentiation. We have yet to detect differences between proteins directly binding to the minimal promoter or the DCR in uninduced and induced MEL cells (deBoer et al. 1988; Philipsen et al. 1990; Talbot et al. 1990). Therefore, we speculate that these differences in pre- and postinduced MEL cells reflect changes in protein factors that mediate the protein-protein interactions.

Early studies on the function of the $\beta$-globin promoter conducted in the presence of viral enhancers in either nonerythroid (Grosveld et al. 1982; Dierks et al. 1983; Myers et al. 1986) or erythroid cells (Cowie and Myers 1988) demonstrated the importance of the CAC and CCAAT box regions as general transcription elements. The results presented here, however, are the first to demonstrate in a quantifiable manner the cooperative interactions between the minimal promoter regions and erythroid-specific regulatory elements and to distinguish the interaction between different elements in different erythroid contexts. Our results highlight the limitations of the early work described above. First, in contrast to studies employing viral enhancers in nonerythroid cells (Dierks et al. 1983), we find that the distal CAC region at -105 is not required for full expression, as the -103 deletion mutant is fully active (Fig. 3,-103). The fact that we fail to find protein factors binding to this region argues further for its non- functional status (deBoer et al. 1988). Of greater significance is our observation that the proximal CAC region and CCAAT box are directly involved and functionally equivalent during the DCR-mediated induced transcription on MEL cell differentiation. Thus, despite the fact that the CAC and CCAAT regions bind different protein factors, the DCR is able to interact with either of these elements in a comparable manner. Furthermore, when both are present, the CAC and CCAAT regions are able to interact synergistically, presumably not only between themselves but also with the DCR to produce full levels of expression. The CAC region has also been found to be a key component in SV40 enhancer function (Xiao et al. 1987) and in steroid hormone-regulated gene expression (Schüle et al. 1988a,b). These observations, in conjunction with those reported here, strongly argue for a general mediatory role for this element in cell-specific gene transcription.

The observation that DCR can work purely through the minimal promoter elements that bind ubiquitous transcription factors also explains why the DCR can reprogram nonglobin heterologous promoters to express in an erythroid-specific manner. For example, the herpes simplex virus (HSV) thymidine kinase (Talbot et al. 1988) and murine Thy-1 (Blom van Assendelft et al. 1989) promoters become inducible in MEL cells in the presence of the DCR, as does that for murine MHC $\mathrm{H}-2 \mathrm{~K}^{\mathrm{k}}$ (O. Hanscombe et al., unpubl.). All of these promoters possess a functional CCAAT or CAC region. Interestingly, the only promoter we have tested that does not respond to the DCR is the murine histone $\mathrm{H} 4$ promoter. This promoter does not contain either a CAC or CCAAT region, although it appears to contain an Splbinding site (Seiler-Tuyns and Birnstiel 1981). This indicates that the crucial factor that binds to the $\beta$-globin

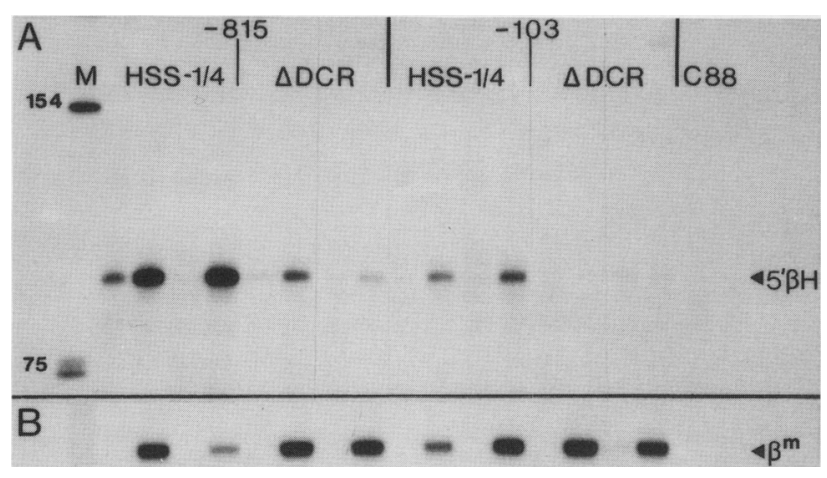

Figure 5. DCR sites 1 and 4 confer and enhance erythroid-specific expression. Expression from the full $(-815)$ and minimal $(-103)$ promoter $\beta \mathrm{H}-2 \mathrm{~K}$ genes linked to DCR sites 1 and 4 (HSS-1/4; see Fig. 4) was compared to that from constructs lacking any DCR elements ( $\triangle D C R)$. RNA $(20 \mu \mathrm{g})$ from MEL cell populations transfected with these constructs was analyzed by S1 nuclease protection (Fig. 2) for $\beta \mathrm{H}-2 \mathrm{~K}$ mRNA $\left(A, 5^{\prime} \beta \mathrm{H}\right) .(B)$ Analysis with $2 \mu \mathrm{g}$ RNA for $\beta^{\text {maj }}$-globin mRNA sequences to assess the level of induced erythroid differentiation of the cells. Each pair of lanes is RNA from preinduced and 4-day-induced cells, respectively. RNA from untransfected cells (C88) acted as a negative control. Size markers (M) were a HinfI digest of pBR322. 
CAC region and can mediate erythroid-specific expression may not be Sp1 but TEF-2 (Xiao et al. 1987).

Our data show that the deletion of either DHS site 2 or 3 in the presence of the full promoter (Fig. 4, top) did not cause a significant drop in $\beta \mathrm{H}-2 \mathrm{~K}$ mRNA levels. The same deletions with the minimal promoter (Fig. 4, bottom), however, showed a substantial decrease to $40 \%$ of full levels when site 3 was deleted. The implications of these observations are at least twofold. First, although the upstream promoter is no longer required to confer erythroid-specific transcription per se, it can still interact synergistically with a DCR lacking DHS site 3 to increase transcription (see also Fig. 5 and below). In addition, these results show that site 3 is more capable than site 2 of producing high-level transcription in the absence of the upstream promoter. This difference in the erythroid capabilities between DHS sites 2 and 3 can best be explained at present by the complement of protein factors that bind to these two regions. A "core" site 2 region of $\sim 250 \mathrm{bp}$, which retains full functional activity in MEL cells, has been characterized (Philipsen et al. 1990). This element is comprised of three tandemly repeated sequences containing one NF-El-binding site juxtaposed with a $\mathrm{G}$-rich region $30 \mathrm{bp}$ downstream. The $\mathrm{G}$-rich sequence resembles the CAC region of the promoter and binds several ubiquitous protein factors, the principal ones being Spl and TEF-2. A similar-sized core site 3 element also has at least three binding sites for NF-E1 (Talbot et al. 1990). In addition, this site 3 region contains a sequence homologous to the Moloney and Friend viral enhancers and also a dimer-binding site for the erythroid-specific factor NF-E2 (Mignotte et al. 1989b). NF-E2 was originally described as a component of the erythroid promoter of the human porphobilinogen deaminase gene and has been shown to be an essential component for its erythroid-specific expression (Mignotte et al. 1989a). Thus, it is conceivable that the Friend viral enhancer sequence and the NF-E2-binding sites combine to make site 3 a more potent and self-contained transcriptional activating region than site 2 , which lacks both of these elements.

Interestingly, the deletion of both DHS sites 2 and 3 does not abolish erythroid-induced transcription from the otherwise noninducible minimal promoter (Fig. 5, cf. -103 HSS-1/4 and $\triangle D C R$ ). It therefore appears that sites 1 and 4 can also completely abolish the requirement for the upstream promoter to produce erythroid-specific expression (Fig. 5; cf. $-815 \Delta \mathrm{DCR}$ and -103 HSS-1/4). In addition, sites 1 and 4 can interact synergistically with the upstream region of the promoter to increase transcription still further (Fig. 5; cf. -815 HSS-1/4 and $\triangle \mathrm{DCR})$. We therefore predict that DHS sites 1 and/or 4 will also be found to bind NF-El and perhaps other protein factors that are common to the promoter region. In summary, it therefore appears that the high levels of expression of $\beta$-globin required in red cells are achieved through the synergistic interaction of local and distant regulatory elements that are binding similar sets of erythroid-specific and ubiquitous transcription factors.

From the results presented here and elsewhere /Collis et al. 1990; Fraser et al. 1990; Philipsen et al. 1990; Talbot et al. 1990), we are now building retroviral constructs consisting of three minimal DCR elements (DHS sites 1,2 , and 3 totaling $1 \mathrm{~kb}$ ) driving expression from the minimal promoter of a $\beta$-globin gene lacking the $3^{\prime}$ enhancer but retaining both introns. Such a small construct can easily be incorporated into a retroviral vector, and its simplicity should maximize the possibility of obtaining sufficiently high viral titers to be of use in bone marrow infection studies. Such work is vital to assess the possibility of corrective gene therapy for $\beta$-thalassemia and sickle cell anemia.

\section{Materials and methods}

Construction of the $\beta H-2 K^{k}$ promoter mutants in the DCR microlocus cassette

The promoter mutants of the $\beta \mathrm{H}-2 \mathrm{~K}^{\mathbf{k}}$ hybrid gene (see Figs. $1-3$ | were adapted from those described previously (Antoniou et al. 1988; deBoer et al. 1988). The point mutants within the minimal promoter were generated by the replacement of the normal sequences between the Ball site at -77 and a ClaI-linkered site at -103 , with a synthetic oligonucleotide bearing the described changes (Fig. 1). The $\beta \mathrm{H}-2 \mathrm{~K}^{\mathbf{k}}$ constructs were cloned between the ClaI and KpnI sites of the DCR microlocus cassette (Collis et al. 1990). Variants of the DCR (see Fig. 4) were prepared by replacing the full, four-site AatIl-ClaI region with the corresponding deletion mutant (see Collis et al. 1990).

All constructs were linearized at the unique PvuI site within the vector before transfection into MEL cells.

\section{Maintenance and transfection of MEL cells}

All manipulations of MEL cells, regarding maintenance, transfection to produce G418-resistance populations, and induced erythroid differentiation, were exactly as described previously (Collis et al. 1990).

\section{Extraction and analysis of RNA}

Extraction of RNA from MEL cells and its analysis by $\mathrm{S} 1 \mathrm{nu}-$ clease protection using end-labeled DNA probes is also as described previously (Antoniou et al. 1988; Collis et al. 1990).

\section{Acknowledgments}

We thank Khai Siew and Phil Collis for technical assistance and Susan Sword for tissue culture support. The secretarial skills of Cora O'Carroll are gratefully acknowledged. M.A. is currently supported by I.C.I. Pharmaceuticals. This work was supported by the Medical Research Council (UK).

\section{References}

Antoniou, M., E. deBoer, G. Habets, and F. Grosveld. 1988. The human $\beta$-globin gene contains multiple regulatory regions: Identification of one promoter and two downstream enhancers. $E M B O$ /. 7: 377-384.

Behringer, R.R., R.E. Hammer, R.L. Brinster, R.D. Palmiter, and T.M. Townes. 1987. Two 3' sequences direct adult erythroid specific expression of human $\beta$-globin genes in transgenic mice. Proc. Natl. Acad. Sci. 84: 7056-7060.

Behringer, R., T. Ryan, P. Reilly, T. Asakura, R. Palmiter, R. Brinster, and T. Townes. 1989. Synthesis of functional human haemoglobin in transgenic mice. Science 245: $971-$ 973.

Blom van Assendelft, M., O. Hanscombe, F. Grosveld, and D.R. 
Greaves. 1989. The $\beta$-globin dominant control region activates homologous and heterologous promoters in a tissuespecific manner. Cell 56: 969-977.

Catala, F., E. deBoer, G. Habets, and F. Grosveld. 1989. Nuclear protein factors and erythroid transcription of the human ${ }^{A} \gamma$ globin gene. Nucleic Acids Res. 10: 3811-3817.

Chodosh, C., A. Baldwin, R. Canthew, and P. Sharp. 1988. Human CCAAT-binding proteins have heterologous subunits. Cell 53: 11-24.

Collis, P., M. Antoniou, and F. Grosveld. 1990. Definition of the minimal requirements within the human $\beta$-globin gene and the dominant control region for high level expression. $E M B O$ I. 9: 233-240.

Cowie, A. and R. Myers. 1988. DNA sequences involved in transcriptional regulation of the mouse $\beta$-globin promoter in murine erythroleukaemia cells. Mol. Cell. Biol. 8: 31223128

deBoer, E., M. Antoniou, V. Mignotte, L. Wall, and F. Grosveld. 1988. The human $\beta$-globin promoter; nuclear protein factors and erythroid specific induction of transcription. EMBO $/$. 7: 4203-4212.

Dierks, P., A. van Ooyen, M. Cochran, C. Dobkin, J. Reiser, and C. Weissmann. 1983. Three regions upstream from the cap site are required for efficient and accurate transcription of the rabbit $\beta$-globin gene in mouse 3 T6 cells. Cell 32: 695706.

Enver, T., A. Evans, W. Forrester, and G. Stamatoyannopoulos. 1989. The human $\beta$-human $\beta$-globin locus activation region alters the developmental fate of a human fetal globin gene in transgenic mice. Proc. Natl. Acad. Sci. 86: 7033-7037.

Evans, T. and G. Felsenfeld. 1989. The erythroid-specific transcription factor Eryf1: A new finger protein. Cell 5: 877885.

Forrester, W., S. Takegawa, T. Papayannopoulou, G. Stamatoyannopoulos, and M. Groudine. 1987. Evidence for a locus activating region: The formation of developmentally stable hypersensitive sites in globin expressing hybrids. Nucleic Acids Res. 15: 10159-10177.

Fraser, P., J. Hurst, P. Collis, and F. Grosveld. 1990. DNase I hypersensitive sites 1,2 and 3 of the human $\beta$-globin dominant control region direct position-independent expression. Nucleic Acids Res. (in press).

Greaves, D.R., F.D. Wilson, G. Lang, and D. Kioussis. 1989. Human CD2 3'-flanking sequences confer high-level, T cellspecific, position-independent gene expression in transgenic mice. Cell 56: 979-986.

Grosveld, G., A. Rosenthal, and R.A. Flavell. 1982. Sequence requirements for the transcription of the rabbit $\beta$-globin gene in vivo: The -80 region. Nucleic Acids Res. 10: $4951-$ 4971.

Grosveld, F., M. Blom van Assendelft, D. Greaves, and G. Kollias. 1987. Position-independent, high-level expression of the human $\beta$-globin gene in transgenic mice. Cell 51: $21-$ 31 .

Hanscombe, O., M. Vidal, J. Kaeda, L. Luzzatto, D.R. Greaves, and F. Grosveld. 1989. High-level, erythroid-specific expression of the human $\alpha$-globin gene in transgenic mice and the production of human hemoglobin in murine erythrocytes. Genes Dev. 3: 1572-1581.

Kollias, G., J. Hurst, E. deBoer, and F. Grosveld. 1987. The human $\beta$-globin gene contains a downstream developmental specific enhancer. Nucleic Acids Res. 15: 5739-5745.

Mignotte, V., J.F. Eleouet, N. Raich, and P.-H. Romeo. 1989a. Cis- and trans-acting elements involved in the regulation of the erythroid promoter of the human porphobilinogen deaminase gene. Proc. Natl. Acad. Sci. 86: 6548-6552.
Mignotte, V., L. Wall, E. deBoer, F. Grosveld, and P.-H. Romeo. $1989 \mathrm{~b}$. Two tissue-specific factors bind the erythroid promoter of the human porphobilinogen deaminase gene. $\mathrm{Nu}$ cleic Acids Res. 17: 37-54.

Myers, R., K. Tilly, and T. Maniatis. 1986. Fine structure genetic analysis of a $\beta$-globin promoter. Science 232: 613-618.

Orkin, S., H. Kazazian, S. Antonarakis, S. Goff, C. Boehm, J. Sexton, P. Waber, and P. Giardina. 1982. Linkage of $\beta$-thalassaemia mutations and $\beta$-globin gene polymorphisms with DNA polymorphisms in human $\beta$-globin gene cluster. $\mathrm{Na}$ ture 296: 627-631.

Orkin, S., S. Antonarakis, and H. Kazazian. 1984. Base substitution at position -88 in a $\beta$-thalassaemic globin gene. J. Biol. Chem. 259: 8679-8681.

Philipsen, S., D. Talbot, P. Fraser, and F. Grosveld. 1990. The $\beta$-globin dominant control region: hypersensitive site 2 . $E M B O$ \%. (in press).

Ryan, T.M., R.R. Behringer, T.M. Townes, R.D. Palmiter, and R.L. Brinster. 1989. High-level erythroid expression of human $\alpha$-globin genes in transgenic mice. Proc. Natl. Acad. Sci. 86: $37-41$.

Schüle, R., M. Muller, C. Kaltschmidt, and R. Renkawitz. 1988a. Many transcription factors interact synergistically with steroid receptors. Science 242: $1418-1420$.

Schüle, R., M. Muller, H. Otsuka-Murakami, and R. Renkawitz. 1988b. Cooperativity of the glucocorticoid receptor and the CACCC-box binding factor. Nature 332: 87-90.

Seiler-Tuyns, A. and M. Birnstiel. 1981. Structure and expression in L-cells of a cloned $\mathrm{H} 4$ histone gene of the mouse. I. Mol. Biol. 151: 607-625.

Talbot, D., P. Collis, M. Antoniou, M. Vidal, F. Grosveld, and D.R. Greaves. 1989. A dominant control region from the human $\beta$-globin locus conferring integration site independent gene expression. Nature 338: 352-355.

Talbot, D., S. Philipsen, P. Fraser, and F. Grosveld. 1990. Detailed analysis of the site region of the human $\beta$-globin dominant control region. $E M B O J$. (in press).

Trainor, C.D., F. Evans, G. Felsenfeld, and M.S. Boguski. 1990. Structure and evolution of a human erythroid transcription factor. Nature 343: 92-96.

Treisman, R., S. Orkin, and T. Maniatis. 1983. Specific transcription and RNA splicing defects in five cloned $\beta$-thalassaemia genes. Nature 302: $591-596$.

Trudel, M., J. Magram, L. Bruckner, and F. Costantini. 1987. Upstream ${ }^{\mathbf{G}} \gamma$-globin and downstream $\beta$-globin sequences required for stage-specific expression in transgenic mice. Mol. Cell. Biol. 7: 4024-4029.

Tsai, S., D. Martin, L. Zou, A. D'Andrea, G. Wang, and S. Orkin. 1989. Cloning of cDNA for the major DNA-binding protein of the erythroid lineage through expression in mammalian cells. Nature 339: 446-451.

Tuan, D., W. Solomon, L. Qiliang, and M. Irving. 1985. The " $\beta$-like globin" gene domain in human erythroid cells. Proc. Natl. Acad. Sci. 82: 6384-6388.

Tuan, D.Y.H., W.B. Solomon, I.M. London, and D.P. Lee. 1989. An erythroid-specific developmental-stage independent enhancer far upstream of the human $\beta$-like globin genes. Proc. Natl. Acad. Sci. 86: 2554-2558.

Wall, L., E. deBoer, and F. Grosveld. 1988. The human $\beta$-globin gene 3 ' enhancer contains multiple binding sites for an erythroid-specific protein. Genes Dev. 2: 1089-1100.

Xiao, J., I. Davidson, M. Macchi, R. Rosales, M. Vigneron, A. Staub, and P. Chambon. 1987. In vitro binding of several cell-specific and ubiquitous nuclear proteins to the GT-I motif of the SV40 enhancer. Genes Dev. 1: 794-807. 


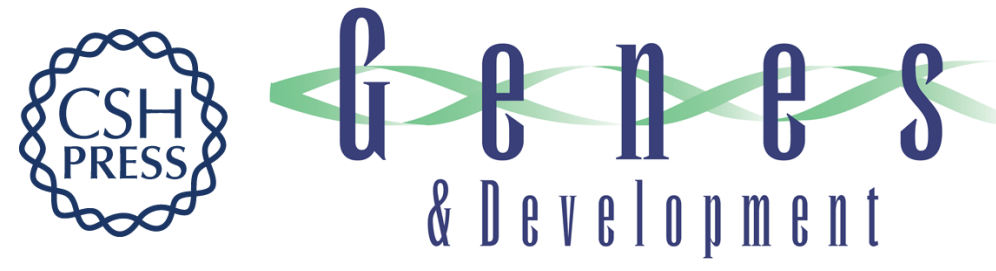

\section{beta-globin dominant control region interacts differently with distal and proximal promoter elements.}

$\mathrm{M}$ Antoniou and F Grosveld

Genes Dev. 1990, 4:

Access the most recent version at doi:10.1101/gad.4.6.1007

References

License

Email Alerting

Service
This article cites 36 articles, 15 of which can be accessed free at: http://genesdev.cshlp.org/content/4/6/1007.full.html\#ref-list-1

Receive free email alerts when new articles cite this article - sign up in the box at the top right corner of the article or click here.

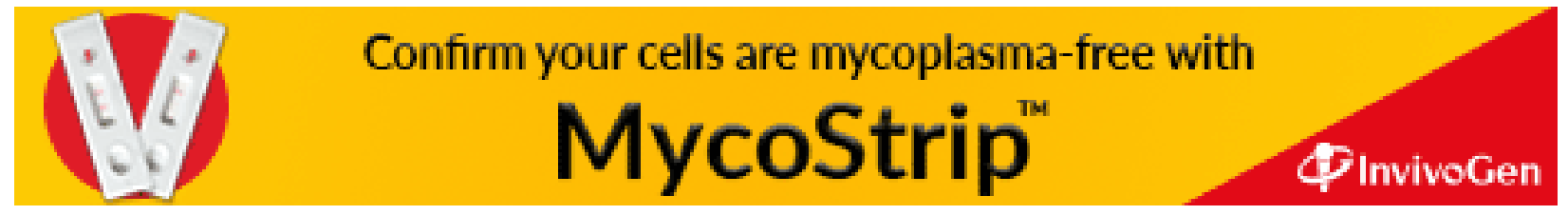

